\title{
THỰC TRẠNG VÀ ĐỂ XUÂT ĐỔI MỚI, HOÀN THIỆN QUY TRİNH LẬP QUY HOẠCH, KẾ HOẠCH SỬ DỤNG ĐẤT CẤP TỈNH
}

\author{
Nguyễn Đắc Nhẫn ${ }^{1}$, Phạm Thị Hồng ${ }^{1}$, Nguyễn Mạnh Thường1
}

Tóm tắt: Quy hoạch, kế hoạch sủ dụng đất có vai trò phân bổ quỹ đất cho các ngành, lĩnh vục nhằm thực hiện các nhiệm vu, muc tiêu, chiến lược, kế hoạch phát triển kinh tế-xã hội, quốc phòng - an ninh. Nghiên cúu áp dụng các phưong pháp khoa hoc truyền thống, nhu: phuơng pháp thu thạp thông tin, tài liệu; phưong pháp kế thùra; phuơng pháp chuyên gia nhằm nâng cao chất lương và tính khả thi của Quy hoạch, kế hoạch sủ dụng đất. Kết quả nghiên cúu trình bày: (i) Quy trình lập phuơng án phân bổ và khoanh vùng đất đai theo khu chức năng và theo loại đất đến tùng đơn vị hành chính cấp huyện (gồm 6 hạng muc) và (ii) Quy trình lập kế hoạch sử dụng đất cấp tỉnh (gồm 5 hang muc). Kết quả nghiên cúu là co sở cho các co quan liên quan và các địa phuơng tham khảo để vận dụng lập quy hoạch, kế hoạch sử dụng đất thời kỳ 2021 - 2030.

Từ khóa: Quy hoạch sủ dụng đất, Quy trình.

Ban Biên tập nhận bài: 12/08/2019 Ngày phản biện xong: 15/09/2019 Ngày đăng bài: 25/10/2019

\section{I. Đặt vấn đề}

Quy hoạch, kế hoạch sử dụng đất có vai trò phân bổ quỹ đất cho các ngành, lĩnh vực nhằm thực hiện các nhiệm vụ, mục tiêu, chiến lược, quy hoạch, kế hoạch phát triển kinh tế - xã hội, quốc phòng - an ninh; quy hoạch, kế hoạch sử dụng đất là cơ sở để các ngành, lĩnh vực lập quy hoạch, kế hoạch phát triển ngành, lĩnh vực; là công cụ quản lý nhà nước về đất đai hiệu quả và là một trong những giải pháp lớn để sử dụng đất đai hợp lý, tiết kiệm, hiệu quả và bảo vệ môi trường sinh thái. Quy hoạch, kế hoạch sử dụng đất cấp tỉnh có vai trò, nhiệm vụ cụ thể hóa một bước quy hoạch, kế hoạch sử dụng đất cấp quốc gia để thực hiện các chỉ tiêu sử dụng đất được phân bổ từ quy hoạch, kế hoạch sử dụng đất cấp quốc gia; đồng thời là quy hoạch trung gian, có vai trò dẫn dắt, định hướng cho quy hoạch, kế hoạch sử dụng đất cấp huyện; phân bổ các chỉ tiêu sử dụng đất cấp quốc gia, cấp tỉnh cho cấp huyện; là cơ sở để thực hiện các chỉ tiêu sử dụng đất phục vụ mục tiêu phát triển kinh tế - xã hội, quốc phòng, an, ninh, bảo vệ môi trường.

Để nâng cao chất lượng của quy hoạch, kế hoạch sử dụng đất, trong đó có Quy hoạch, kế hoạch sử dụng đất cấp tỉnh, nhằm ngày càng khẳng định vai trò, vị trí và tầm quan trọng của quy hoạch, kế hoạch sử dụng đất, các quy định của pháp luật đất đai về quy hoạch, kế hoạch sử dụng đất nói chung, về nội dung quy trình lập quy hoạch, kế hoạch sử dụng đất cấp tỉnh nói riêng ngày càng được đổi mới, hoàn thiện. Thời kỳ từ Luật Đất đai năm 1987 đến Luật Đất đai năm 1993: Các văn bản pháp luật về đất đai có quy định về quy hoạch sử dụng đất, gồm Luật Đất đai năm 1987 [8]; Nghị định số 30/HĐBT [7]; Thông tư số 106/TT-QLĐĐ [19]. Tuy nhiên, các văn bản này chưa có quy định về quy trình lập, điều chỉnh quy hoạch, kế hoạch sử dụng đất cấp tỉnh.

Thời kỳ từ Luật Đất đai 1993 đến Luật Đất đai năm 2003: Công tác quy hoạch, kế hoạch sử dụng đất được thực hiện theo quy định của các văn bản quy phạm pháp luật, gồm: Luật Đất đai 1993 [9]; Nghị định số 68/2001/NĐ-CP [3] và các văn bản hướng dẫn chuyên ngành của Tổng cục Địa chính, gồm: Quyết định số 657/QĐ-ĐC [15], Công văn số 1814/CV-TCĐC [16], Thông

${ }^{1}$ Cục quy hoạch đất đai

Email:ndnhan@monre.gov.vn; hongcqh@gmail.com 
tư số 1842/2001/TT-TCĐC [14], Quyết định số 424a/2001/QĐ-TCĐC [17] và Quyết định số 424b/2001/QĐ-TCĐC [18]. Theo đó, quy trình lập quy hoạch, kế hoạch sử dụng đất được quy định chung cho các cấp, trong đó có cấp tỉnh, gồm: (1) Quy trình lập quy hoạch sử dụng đất theo Quyết định số 657/QĐ-ĐC gồm 9 hạng mục; (2) Quy trình lập quy hoạch sử dụng đất có 3 hạng mục theo Thông tư số 1842/2001/TTTCĐC [14]; (3) Quy trình lập kế hoạch sử dụng đất có 4 hạng mục theo Thông tư số 1842/2001/TT-TCĐC [14].

Thời kỳ từ Luật Đất đai 2003 đến Luật Đất đai năm 2013 được chia làm 2 giai đoạn: Giai đoạn đầu, từ ngày Luật Đất đai năm 2003 [10] có hiệu lực đến khi có Nghị định số 69/2009/NĐ-CP [5], Quy trình lập, điều chỉnh quy hoạch, kế hoạch sử dụng đất cấp tỉnh được thực hiện theo Nghị định số 181/2004/NĐ-CP [4]. Theo đó, có 3 loại quy trình, gồm: (1) Quy trình lập quy hoạch sử dụng đất, kế hoạch sử dụng đất kỳ đầu cấp tỉnh gồm 15 nội dung công việc, (2) Quy trình lập kế hoạch sử dụng đất kỳ cuối cấp tỉnh gồm 04 nội dung công việc, (3) Quy trình điều chỉnh quy hoạch, kế hoạch sử dụng đất cấp tỉnh gồm 02 nội dung công việc. Giai đoạn sau từ khi có Nghị định số 69/2009/NĐ-CP đến ngày Luật Đất đai năm 2013 [11] có hiệu lực, Quy trình lập, điều chỉnh quy hoạch, kế hoạch sử dụng đất cấp tỉnh thực hiện theo Thông tư số 19/2009/TT-BTNMT [1], gồm có 03 quy trình: (1) Quy trình lập quy hoạch sử đất, kế hoạch sử dụng đất kỳ đầu cấp tỉnh gồm 7 hạng mục; (2) Quy trình lập kế hoạch sử dụng đất kỳ cuối cấp tỉnh gồm 4 hạng mục; (3) Quy trình điều chỉnh quy hoạch, kế hoạch sử dụng đất cấp tỉnh gồm 2 hạng mục.

Thời kỳ từ Luật Đất đai năm 2013 đến nay: Công tác quy hoạch, kế hoạch sử dụng đất được thực hiện theo quy định của các văn bản quy phạm pháp luật, gồm: Luật Đất đai năm 2013 [11], Nghị định số 43/2014/NĐ-CP [6], Thông tư số 29/2014/TT-BTNMT [2]. Theo đó, quy trình lập, điều chỉnh quy hoạch, kế hoạch sử dụng đất cấp tỉnh gồm 4 quy trình: (1) Quy trình lập quy hoạch sử dụng đất và kế hoạch sử dụng đất kỳ đầu cấp tỉnh gồm 7 hạng mục, (2) Quy trình điều chỉnh quy hoạch sử dụng đất và lập kế hoạch sử dụng đất kỳ cuối cấp tỉnh gồm 5 hạng mục, (3) Quy trình lập kế hoạch sử dụng đất kỳ cuối cấp tỉnh gồm 4 hạng mục, (4) Quy trình điều chỉnh kế hoạch sử dụng đất cấp tỉnh gồm 4 hạng mục. Như vậy công tác quy hoạch, kế hoạch sử dụng đất đã được quan tâm từ rất sớm; hệ thống văn bản về công tác quy hoạch, kế hoạch sử dụng đất được hình thành và ngày càng hoàn thiện để kịp thời đáp ứng yêu cầu thực tiễn công tác quản lý nhà nước về đất đai; quy trình lập quy hoạch, kế hoạch sử dụng đất cấp tỉnh cũng được từng bước hoàn thiện, tạo hành lang pháp lý ngày càng đầy đủ hơn, phục vụ kịp thời yêu cầu phát triển kinh tế - xã hội của đất nước theo từng thời kỳ lịch sử. Tuy đã đạt được những thành tựu không nhỏ, góp phần phát triển kinh tế - xã hội song công tác quy hoạch, kế hoạch sử dụng đất, trong đó có quy trình lập quy hoạch, kế hoạch sử dụng đất vẫn còn một số tồn tại bất cập cần được nghiên cứu khắc phục.

- Công tác điều tra cơ bản là luôn là hạng mục đầu tiên trong quy trình, có vai trò quan trọng trong việc thu thập dữ liệu đầu vào nhưng trong quy trình chưa quy định trách nhiệm đầy đủ cho các cơ quan, tổ chức, các cấp, các ngành có liên quan, đặc biệt là việc đăng ký nhu cầu sử dụng đất của các ngành, lĩnh vực và các địa phương nên tính đầy đủ, toàn diện của dữ liệu đầu vào còn hạn chế, ảnh hưởng đến độ tin cậy, tính khả thi của phương án quy hoạch.

- Nội dung thẩm định quy hoạch, kế hoạch sử dụng đất chưa được quy định đầy đủ, rõ ràng trong quy trình nên công tác thẩm định còn mang tính hình thức, chưa có phương pháp khoa học, chỉ được thực hiện trong phòng, trên cơ sở báo cáo của cấp dưới và các cơ quan tư vấn, mà chưa có sự kiểm tra ngoài thực địa; dẫn đến chất lượng thẩm định còn hạn chế, phương án quy hoạch được duyệt thiếu tính khả thi, khó thực hiện.

- Nội dung công việc của hạng mục xây dựng phương án quy hoạch, kế hoạch sử dụng đất trong quy trình chưa được quy định chi tiết trong 
quy trình nên việc tính toán, xác định các chỉ tiêu sử dụng đất còn lúng túng (đặc biệt đối với một số tư vấn còn ít kinh nghiệm). Điều này đã dẫn đến phương án quy hoạch, kế hoạch sử dụng đất không phù hợp với quy hoạch cấp trên và tình hình thực tế của địa phương.

- Việc tham gia ý kiến của người dân vào quy hoạch, kế hoạch sử dụng đất tuy đã có nhiều cải tiến, đổi mới song trong quy trình vẫn chưa có quy định chi tiết, cụ thể về nội dung, phương pháp nên việc lấy ý kiến người dân ở một số địa phương chưa được thực chất. Do đó chất lượng của phương án quy hoạch bị ảnh hưởng, phương án quy hoạch được duyệt thiếu tính khả thi, khó đi vào thực tiễn.

- Công tác công bố công khai quy hoạch sử dụng đất đã có quy định nhưng chưa hướng dẫn chi tiết, cụ thể về nội dung trong quy trình nên trong quá trình thực hiện còn gặp một số khó khăn, như thiếu nguồn kinh phí để triển khai các công việc; lúng túng trong việc áp dụng phương pháp, công nghệ công bố công khai quy hoạch sử dụng đất... Do vậy, việc tiếp cận và hiểu biết của người dân đối với phương án quy hoạch sử dụng đất còn hạn chế, gây khó khăn trong thực hiện và giám sát thực hiện quy hoạch sử dụng đất.

Với mục tiêu đổi mới, hoàn thiện quy trình lập quy hoạch, kế hoạch sử dụng đất cấp tỉnh phù hợp với tình hình phát triển kinh tế - xã hội và tiến bộ khoa học công nghệ, nhằm nâng cao chất lượng của quy hoạch, kế hoạch sử dụng đất cấp tỉnh, góp phần quản lý, sử dụng tài nguyên đất hiệu quả, bền vững trong điều kiện biến đổi khí hậu phức tạp, khó lường; nhóm nghiên cứu đã nghiên cứu "Thực trạng và đề xuất đổi mới, hoàn thiện quy trình lập quy hoạch, kế hoạch sử dụng đất cấp tỉnh", đây là một trong những nội dung trọng tâm của đề tài NCKH cấp quốc gia: "Nghiên cứu cơ sở khoa học, đề xuất đổi mới phương pháp luận và ứng dụng công nghệ trong công tác quy hoạch, kế hoạch sử dụng đất nhằm góp phần quản lý, sử dụng tài nguyên đất hiệu quả, bền vững".

\section{Phương pháp nghiên cứu}

- Phương pháp thu thập thông tin, tài liệu: thu thập các thông tin, tài liệu ở các cơ quan trung ương và địa phương, gồm các báo cáo, số liệu, tài liệu của các ngành, lĩnh vực có liên quan.

- Phương pháp kế thừa: Kế thừa có chọn lọc các nội dung quy trình lập quy hoạch, kế hoạch sử dụng đất đã được triển khai từ hơn 30 mươi năm nay để nghiên cứu đổi mới, hoàn thiện quy trình lập quy hoạch, kế hoạch sử dụng đất cấp tỉnh.

- Phương pháp chuyên gia: Khai thác sử dụng kinh nghiệm, trí tuệ của đội ngũ chuyên gia để xem xét, nhận định, phân tích, đánh giá những đề xuất mới để những đề xuất mới đảm bảo phù hợp với tình hình phát triển kinh tế - xã hội và tiến bộ khoa học công nghệ.

\section{Kết quả nghiên cứu và thảo luận}

Luật Quy hoạch đã có hiệu lực; theo quy định của Luật Quy hoạch thì trong hệ thống quy hoạch quốc gia không có Quy hoạch sử dụng đất cấp tỉnh đứng độc lập mà được tích hợp vào Quy hoạch tỉnh với hợp phần có tên gọi là "Phương án phân bổ và khoanh vùng đất đai theo khu chức năng và theo loại đất đến từng đơn vị hành chính cấp huyện" (sau đây gọi tắt là "Phương án phân bổ và khoanh vùng đất đai cấp tỉnh”). Tuy nhiên, nội hàm "Phương án phân bổ và khoanh vùng đất đai cấp tỉnh" chính là "Phương án quy hoạch sử dụng đất cấp tỉnh".

Do vậy, để kịp thời phục vụ công tác triển khai thực hiện Luật Quy hoạch, trên cơ sở nghiên cứu lý luận và thực tiễn, kế thừa quy định hiện hành, trong khuôn khổ bài viết này, nhóm nghiên cứu đề xuất đổi mới, hoàn thiện 2 quy trình:

- Quy trình 1: "Lập phương án phân bổ và khoanh vùng đất đai cấp tỉnh" để tích hợp vào Quy hoạch tỉnh.

- Quy trình 2: "Lập kế hoạch sử dụng đất cấp tỉnh"

Nội dung của từng quy trình như sau:

\subsection{Quy trình 1 - Lập phương án phân bổ và khoanh vùng đất đai cấp tỉnh}

Quy trình lập phương án phân bổ và khoanh vùng đất đai cấp tỉnh gồm 6 hạng mục được thể hiện trên hình 1. 


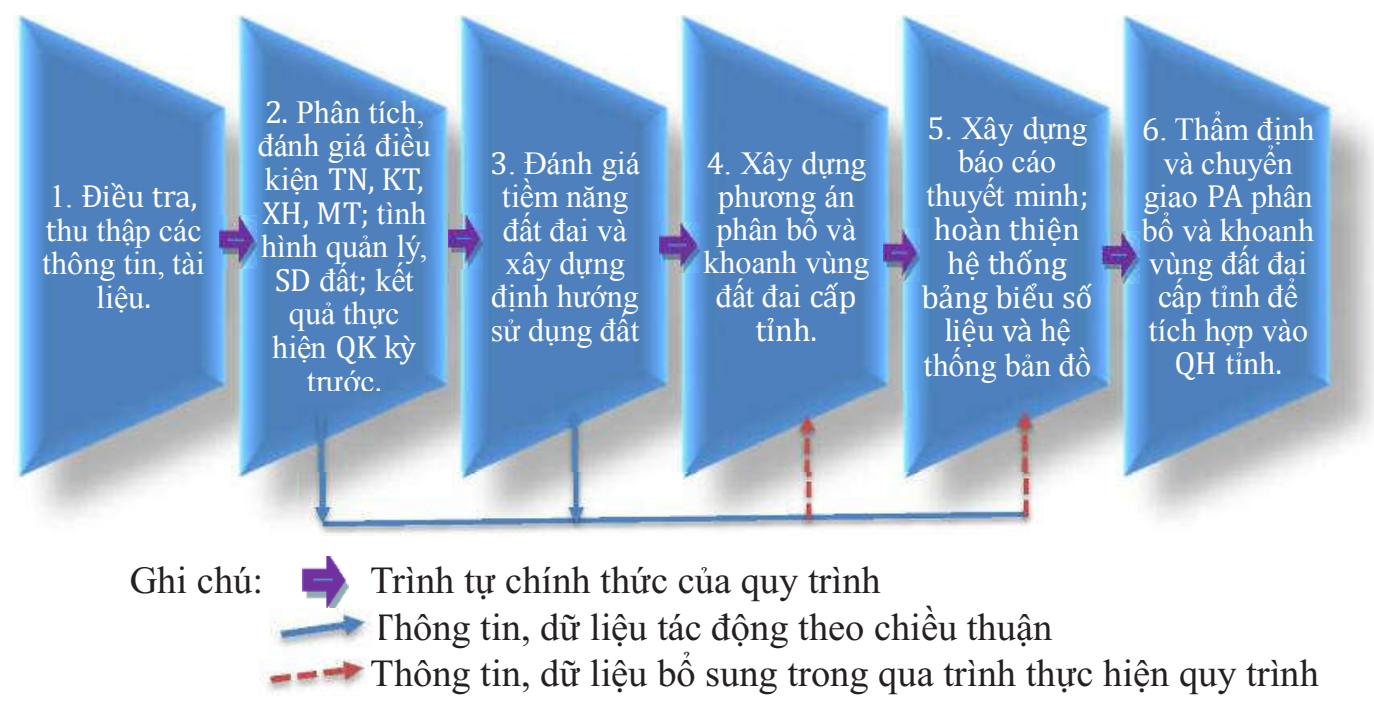

Hình 1. So đồ quy trình Lập phương án phân bổ và khoanh vùng đất đai cấp tỉnh

Nội dung của từng hạng mục công việc như sau:

Hạng muc 1: Điều tra, thu thập các thông tin, tài liệu

1. Thu thập các thông tin, tài liệu có liên quan đến việc lập phương án phân bổ và khoanh vùng đất đai cấp tỉnh từ Cơ quan được giao lập quy hoạch tỉnh, gồm:

a) Báo cáo kết quả thu thập và xử lý tài liệu, số liệu; nhu cầu sử dụng đất của các ngành, lĩnh vực và của cấp huyện.

b) Kết quả phân tích, đánh giá, dự báo về các yếu tố, điều kiện phát triển đặc thù của địa phương.

c) Kết quả đánh giá thực trạng phát triển kinh tế - xã hội, hiện trạng hệ thống đô thị và nông thôn.

d) Định hướng về quan điểm và mục tiêu phát triển tỉnh; phương hướng phát triển các ngành quan trọng trên địa bàn tỉnh.

đ) Phương án bố trí không gian các công trình, dự án quan trọng, các vùng bảo tồn đã được xác định ở quy hoạch cấp quốc gia, quy hoạch cấp vùng trên địa bàn tỉnh; dự thảo phương án kết nối hệ thống hạ tầng của tỉnh với hệ thống hạ tầng quốc gia và vùng; dự thảo phương án tổ chức không gian các hoạt động kinh tế - xã hội, quốc phòng, an ninh, bảo vệ môi trường ở cấp tỉnh, liên huyện.

2. Tổng hợp, phân tích, đánh giá nhu cầu sủ̉ dụng đất của các ngành, lĩnh vực và của cấp huyện.

3. Điều tra, khảo sát thực địa

a) Xác định những nội dung cần điều tra khảo sát thực địa; xây dựng kế hoạch khảo sát thực địa;

b) Điều tra, khảo sát thực địa;

c) Chỉnh lý bổ sung thông tin, tài liệu trên cơ sở kết quả điều tra, khảo sát thực địa.

4. Tổng hợp, xử lý các thông tin, tài liệu.

5. Xây dựng báo cáo chuyên đề về kết quả điều tra, thu thập các thông tin, tài liệu.

6. Hội thảo; chỉnh sửa, hoàn thiện báo cáo chuyên đề sau hội thảo.

7. Đánh giá, nghiệm thu Hạng mục 1.

Hạng muc 2: Phân tích, đánh giá điều kiện tụ nhiên, kinh tế - xã hội và môi trường tác động đến việc sủ dụng đất; tình hình quản lý, sủ dụng đất; kết quả thực hiện các chỉ tiêu sủ dụng đất trong kỳ quy hoạch truớc.

1. Phân tích, đánh giá điều kiện tự nhiên, các nguồn tài nguyên và môi trường có tác động đến việc sử dụng đất;

2. Phân tích, đánh giá thực trạng phát triển kinh tế - xã hội có tác động đến việc sử dụng đất;

3. Phân tích, đánh giá về biến đổi khí hậu tác động đến việc sử dụng đất, gồm: Nước biển dâng, xâm nhập mặn, sa mạc hóa, xói mòn, sạt lở đất.

4. Phân tích, đánh giá tình hình thực hiện một 
số nội dung quản lý nhà nước về đất đai liên quan đến việc thực hiện quy hoạch sử dụng đất.

5. Phân tích, đánh giá hiện trạng và biến động sử dụng đất theo từng loại đất trong 10 năm trước.

6. Phân tích, đánh giá kết quả thực hiện các chỉ tiêu sử dụng đất trong kỳ quy hoạch trước.

7. Lập bản đồ hiện trạng sử dụng đất phục vụ quy hoạch sử dụng đất.

8. Xây dựng các báo cáo chuyên đề.

9. Hội thảo và chỉnh sửa báo cáo chuyên đề, bản đồ sau hội thảo.

10. Đánh giá, nghiệm thu Hạng mục 2.

Hạng muc 3: Đánh giá tiềm năng đất đai và xây dưng định hướng sư dụng đất cho 20 năm:

1. Đánh giá tiềm năng đất đai:

a) Phân tích, đánh giá tiềm năng đất đai cho lĩnh vực nông nghiệp;

b) Phân tích, đánh giá tiềm năng đất đai cho lĩnh vực phi nông nghiệp.

2. Xây dựng định hướng sử dụng đất:

a) Khái quát phương hướng, mục tiêu phát triển kinh tế - xã hội;

b) Xây dựng quan điểm sử dụng đất;

c) Xây dựng định hướng sử dụng đất cho lĩnh vực nông nghiệp, lĩnh vực phi nông nghiệp; định hướng sử dụng đất theo khu chức năng.

3. Lập bản đồ tiềm năng đất đai và bản đồ định hướng sử dụng đất.

4. Xây dựng các báo cáo chuyên đề.

5. Hội thảo và chỉnh sửa báo cáo chuyên đề, bản đồ sau hội thảo.

6. Đánh giá, nghiệm thu Hạng mục 3.

Hạng muc 4: Xây dựng phương án phân bổ và khoanh vùng đất đai cấp tỉnh

1. Xác định các chỉ tiêu sử dụng đất đã được quy hoạch sử dụng đất quốc gia phân bổ cho cấp tỉnh đến từng đơn vị hành chính cấp huyện (các chỉ tiêu sử dụng đất này được thể hiện trong quy trình lập quy hoạch sử dụng đất quốc gia)

2. Xác định các chỉ tiêu sử dụng đất trong kỳ quy hoạch theo thẩm quyền cấp tỉnh, bao gồm:

a) Nhóm đất nông nghiệp gồm: Đất trồng lúa, Đất trồng cây hàng năm khác, Đất trồng cây lâu năm, Đất nuôi trồng thủy sản, Đất làm muối; xác định bổ sung diện tích các loại đất nông nghiệp đối với các chỉ tiêu quốc gia phân bổ (nếu có).

b) Nhóm đất phi nông nghiệp gồm: Đất cụm công nghiệp, Đất thương mại, dịch vụ, Đất cơ sở sản xuất phi nông nghiệp, Đất sử dụng cho hoạt động khoáng sản, Đất ở tại nông thôn, Đất ở tại đô thị, Đất xây dựng trụ sở cơ quan, Đất xây dựng trụ sở của tổ chức sự nghiệp, Đất xây dựng cơ sở ngoại giao, Đất cơ sở tôn giáo, Đất làm nghĩa trang, nghĩa địa, nhà tang lễ, nhà hỏa táng.

c) Diện tích đất chưa sử dụng đưa vào sử dụng cho các mục đích nông nghiệp, phi nông nghiệp trong kỳ kế hoạch (ngoài diện tích quốc gia phân bổ).

d) Chỉ tiêu chuyển mục đích sử dụng đất đối với các loại đất (đất trồng lúa, đất rừng) phải xin phép của Hội đồng nhân dân cấp tỉnh theo quy định của pháp luật đất đai để thực hiện các công trình, dự án quốc phòng, an ninh, phát triển kinh tế - xã hội vì lợi ích quốc gia, lợi ích công cộng.

đ) Chỉ tiêu chuyển mục đích sử dụng đất đối với các loại đất (trừ các loại đất phải xin phép của Quốc hội, Chính phủ, Thủ tướng Chính phủ hoặc Hội đồng nhân dân cấp tỉnh) để đáp ứng yêu cầu sử dụng đất của các ngành, lĩnh vực.

e) Các chỉ tiêu sử dụng đất cấp tỉnh theo không gian sử dụng, bao gồm:

- Diện tích, cơ cấu các chỉ tiêu SD đất theo khu chức năng, gồm: Khu sản xuất nông nghiệp ứng dụng công nghệ cao, Khu lâm nghiệp, Khu bảo tồn thiên nhiên và đa dạng sinh học, Khu đất ngập nước, Khu thương mại - dịch vụ, Khu dân cư nông thôn.

- Các vùng phát triển đô thị, không gian các đô thị mới; phân khu chức năng các đô thị mới.

- Chỉ tiêu sử dụng đất đối với không gian ngầm tại các đô thị, khu trung tâm thương mại dịch vụ tập trung, khu trung tâm hành chính, khu kết cấu hạ tầng tập trung trên địa bàn tỉnh.

3. Tổng hợp các chỉ tiêu sử dụng đất trên địa bàn tỉnh và phân bổ đến từng đơn vị hành chính cấp huyện.

4. Đánh giá tác động đến kinh tế, xã hội và môi trường của phương án phân bổ và khoanh vùng đất đai theo khu chức năng và theo loại đất. 
5. Phân kỳ phương án phân bổ và khoanh vùng đất đai theo khu chức năng và theo loại đất:

a) Xác định nhu cầu sử dụng các loại đất trong mỗi kỳ $\mathrm{KH}$ sử dụng đất 5 năm;

b) Cân đối, phân bổ quỹ đất cho từng kỳ kế hoạch sử dụng đất 5 năm theo từng loại đất

6. Xác định các giải pháp thực hiện phương án phân bổ và khoanh vùng đất đai theo khu chức năng và theo loại đất:

a) Xác định các giải pháp bảo vệ, cải tạo đất và bảo vệ môi trường;

b) Xác định các giải pháp tổ chức thực hiện;

7. Xây dựng hệ thống bảng, biểu số liệu phân tích, sơ đồ, biểu đồ.

8. Lập bản đồ quy hoạch sử dụng đất.

9. Xây dựng các báo cáo chuyên đề.

10. Hội thảo và chỉnh sửa báo cáo, bản đồ sau hội thảo.

11. Đánh giá, nghiệm thu Hạng mục 4.

Hạng muc 5: Xây dựng báo cáo thuyêt minh; hoàn thiện hệ thống bảng biểu số liệu và hệ thống bản đồ

1. Xây dựng báo cáo thuyết minh.

2. Hoàn thiện hệ thống bảng, biểu số liệu, sơ đồ, biểu đồ.

3. Hoàn thiện hệ thống bản đồ ((BĐ hiện trạng và $\mathrm{BĐ}$ quy hoạch sử dụng đất)

4. Hội thảo; hoàn thiện báo cáo thuyết minh; hệ thống bảng, biểu số liệu, sơ đồ, biểu đồ; hệ thống bản đồ quy hoạch sử dụng đất sau hội thảo.

7. Báo cáo Ủy ban nhân dân cấp tỉnh phương án phân bổ và khoanh vùng đất đai; chỉnh sửa, hoàn thiện hồ sơ, tài liệu sau báo cáo.

8. Đánh giá, nghiệm thu Hạng mục 5.

Hạng muc 6: Thẩm định và chuyển giao phưong án phân bổ và khoanh vùng đất đai cấp tỉnh để tích hơp vào quy hoạch tỉnh.

1. Thẩm định phương án phân bổ và khoanh vùng đất đai:

a) Nộp báo cáo thuyết minh phương án phân bổ và khoanh vùng đất đai và hồ sơ, tài liệu kèm theo về Bộ Tài nguyên và Môi trường để thẩm định;

b) Tổ chức thẩm định;

c) Chỉnh sửa, hoàn thiện hồ sơ, tài liệu sau thẩm định.

2. Chuyển giao phương án phân bổ và khoanh vùng đất đai cấp tỉnh cho cơ quan lập quy hoạch tỉnh để tích hợp vào quy hoạch tỉnh.

3. Đánh giá, nghiệm thu Hạng mục 5

4. Giao nộp sản phẩm Dự án.

\subsection{Quy trình 2 - Lập kế họch sử dung đất} cấp tỉnh

Quy trình lập kế hoạch sử dụng đất cấp tỉnh gồm 5 hạng mục, nội dung của từng hạng mục công việc như sau:

Hạng muc 1: Điều tra, thu thập thông tin, tài liệu.

1. Thu thập các thông tin, tài liệu:

a) Thu thập các thông tin, tài liệu liên quan đến điều kiện tự nhiên, kinh tế, xã hội và môi trường tác động đến việc sử dụng đất; tình hình quản lý, sử dụng đất; kết quả thực hiện kế hoạch sử dụng đất kỳ trước;

b) Thu thập các thông tin, tài liệu về nhu cầu sử dụng đất và các công trình dự án có sử dụng đất trong kỳ kế hoạch do các ngành, lĩnh vực và Ủy ban nhân dân cấp huyện xác định và đề xuất (quy trình thực hiện như mục 1, 2 và 3 Hạng mục 1 của Quy trình 1).

c) Điều tra, khảo sát thực địa.

2. Tổng hợp, xử lý các thông tin, tài liệu và lập báo cáo chuyên đề về kết quả điều tra, thu thập các thông tin, tài liệu.

3. Hội thảo và chỉnh sửa, hoàn thiện báo cáo chuyên đề sau hội thảo.

4. Đánh giá, nghiệm thu Hạng mục 1.

Hạng muc 2: Phân tích, đánh giá điều kiện tụ nhiên, kinh tế, xã hội và môi trường; tình hình quản lý, sủ dụng đất; kết quả thục hiện kế hoạch sư dụng đất kỳ trước.

1. Phân tích, đánh giá điều kiện tự nhiên, kinh tế, xã hội và môi trường:

a) Phân tích, đánh giá điều kiện $\mathrm{TN}$, các nguồn tài nguyên và hiện trạng môi trường;

b) Phân tích, đánh giá thực trạng phát triển kinh tế - xã hội;

c) Phân tích, đánh giá về biến đổi khí hậu tác động đến việc sử dụng đất.

2. Phân tích, đánh giá tình hình quản lý, sử 
dụng đất; hiện trạng sử dụng đất:

a) Phân tích, đánh giá tình hình thực hiện một số nội dung quản lý nhà nước về đất đai.

b) Phân tích, đánh giá hiện trạng sử dụng đất.

3. Phân tích, đánh giá kết quả thực hiện kế hoạch sử dụng đất kỳ trước.

4. Xây dựng các báo cáo chuyên đề.

5. Hội thảo và chỉnh sửa, hoàn thiện báo cáo chuyên đề sau hội thảo.

6. Đánh giá, nghiệm thu Hạng mục 2.

Hạng muc 3: Lâp kế hoạch sủ dụng đất

1. Khái quát phương hướng, mục tiêu phát triển KT-XH trong kỳ kế hoạch.

2. Xây dựng kế hoạch sử dụng đất:

a) Tổng hợp các chỉ tiêu sử dụng đất của kế hoạch sử dụng đất kỳ trước chưa thực hiện để xem xét đưa vào kế hoạch sử dụng đất kỳ này;

b) Xác định các chỉ tiêu sử dụng đất trong kỳ kế hoạch đã được kế hoạch sử dụng đất cấp quốc gia phân bổ cho cấp tỉnh và phân bổ đến từng đơn vị hành chính cấp huyện.

c) Xác định các chỉ tiêu sử dụng đất trong kỳ kế hoạch theo thẩm quyền cấp tỉnh (bao gồm các chỉ tiêu sử dụng đất nêu tại các Mục 2 Hạng mục 4 của Quy trình 1).

d) Tổng hợp các chỉ tiêu kế hoạch sử dụng đất trên địa bàn tỉnh và phân bổ đến từng đơn vị hành chính cấp huyện.

đ) Dự kiến các nguồn thu từ giao đất, cho thuê đất, chuyển mục đích sử dụng đất và các khoản chi cho việc bồi thường, hỗ trợ, tái định cư theo kế hoạch sử dụng đất.

e) Xác định các giải pháp thực hiện kế hoạch sử dụng đất.

3. Xây dựng hệ thống bảng, biểu số liệu phân tích, sơ đồ, biểu đồ.

4. Lập bản đồ kế hoạch sử dụng đất.

5. Xây dựng báo cáo chuyên đề.

6. Hội thảo và chỉnh sửa báo cáo, bản đồ sau hội thảo.

7. Đánh giá, nghiệm thu Hạng mục 3.

Hạng mục 4: Xây dụng báo cáo thuyết minh tổng hợp, bản đồ và các tài liệu có liên quan

1. Xây dựng báo cáo thuyết minh tổng hợp.

2. Hoàn thiện bảng, biểu số liệu, sơ đồ, biểu đồ; hệ thống bản đồ kế hoạch sử dụng đất

3. Hội thảo; hoàn thiện báo cáo thuyết minh tổng hợp, bảng, biểu số liệu, sơ đồ, biểu đồ, hệ thống bản đồ kế hoạch sử dụng đất sau hội thảo.

4. Soạn thảo các văn bản trình duyệt kế hoạch sử dụng đất; nhân sao hồ sơ, tài liệu phục vụ trình duyệt kế hoạch sử dụng đất.

5. Báo cáo Ưy ban nhân dân cấp tỉnh kế hoạch sử dụng đất; chỉnh sửa, hoàn thiện hồ sơ, tài liệu sau báo cáo.

6. Đánh giá, nghiệm thu.

Hạng muc 5: Thẩm định, phê duyệt và công bố công khai kế hoạch sư dụng đất

1. Thẩm định kế hoạch sử dụng đất.

a) Nộp báo cáo thuyết minh tổng hợp kế hoạch sử dụng đất và hồ sơ, tài liệu kèm theo về Bộ Tài nguyên và Môi trường để thẩm định;

b) Tổ chức thẩm định;

c) Chỉnh sửa, hoàn thiện hồ sơ, tài liệu sau thẩm định.

2. Trình Thủ tướng Chính phủ phê duyệt kế hoạch sử dụng đất (thông qua Bộ Tài nguyên và Môi trường).

3. Thực hiện công bố công khai kế hoạch sử dụng đất cấp tỉnh sau khi được Thủ tướng Chính phủ phê duyệt.

4. Đánh giá, nghiệm thu Hạng mục 5.

5. Giao nộp sản phẩm Dự án.

\section{KẾT LUẬN}

Trên cơ sơ nghiên cứu khoa học và thực tiễn triển khai công tác lập, điều chỉnh quy hoạch, kế hoạch sử dụng đất cấp tỉnh, nhóm nghiên cứu đã đề xuất đổi mới, hoàn thiện quy trình lập quy hoạch, kế hoạch sử dụng đất cấp tỉnh. Trong khuôn khổ bài viết này, nhóm nghiên cứu trình bày 02 quy trình, gồm:

1. Quy trình 1 - Lập phương án phân bổ và khoanh vùng đất đai cấp tỉnh gồm 06 hạng mục:

Hạng mục 1. Điều tra, thu thập các thông tin, tài liệu.

Hạng mục 2. Phân tích, đánh giá điều kiện tự nhiên, kinh tế - xã hội và môi trường tác động đến việc sử dụng đất; tình hình quản lý, sử dụng đất; kết quả thực hiện các chỉ tiêu sử dụng đất trong kỳ quy hoạch trước. 
Hạng mục 3. Đánh giá tiềm năng đất đai và xây dựng định hướng SD đất cho 20 năm.

Hạng mục 4. Xây dựng phương án phân bổ và khoanh vùng đất đai cấp tỉnh.

Hạng mục 5. Xây dựng báo cáo thuyết minh, bảng biểu số liệu và hệ thống bản đồ.

Hạng mục 6. Thẩm định và chuyển giao phương án phân bổ và khoanh vùng đất đai cấp tỉnh để tích hợp vào quy hoạch tỉnh.

2. Quy trình 2 - Lập kế hoạch sử dụng đất cấp tỉnh gồm 05 hạng mục sau:
Hạng mục 1. Điều tra, thu thập các thông tin, tài liệu.

Hạng mục 2. Phân tích, đánh giá điều kiện tự nhiên, kinh tế, xã hội và môi trường; tình hình quản lý, sử dụng đất; kết quả thực hiện kế hoạch sử dụng đất kỳ trước.

Hạng mục 3. Lập kế hoạch sử dụng đất.

Hạng mục 4. Xây dựng báo cáo thuyết minh tổng hợp, bản đồ và các tài liệu có liên quan.

Hạng mục 5. Thẩm định, phê duyệt và công bố công khai kế hoạch sử dụng đất.

Lời cảm ơn: Để hoàn thành công trình này, Nhóm nghiên cúu Đề tài BĐKH.09/16-20 đã nhận được sư giúp đỡ chân thành, nhiệt tình của nhiều cơ quan, tổ chức; của các chuyên gia, các nhà khoa họ và các đồng nghiệp. Nhân dịp này, chúng tôi xin trân trọng cảm ơn Văn phòng Chuơng trình Khoa học và Công nghệ cấp quốc gia về Tài nguyên Môi truờng và Biến đổi khí hậu - Bộ Tài nguyên và Môi trường; Tổng cuc Quản lý đất đai; Cục Quy hoạch đất đai; Viện Nghiên cứu quản lý đất đai; các chuyên gia, các nhà nhà khoa học và các đồng nghiệp đã giúp đõ̃ chúng tôi trong suốt quá trình nghiên cứu và đã có nhũng đóng góp ý kiến quý báu để nhóm nghiên cứu chúng tôi hoàn thành công trình này. Trên cơ sở đó, góp phần nâng cao chất lương của quy hoạch, kế hoạch sử dụng đất, nhằm ngày càng khẳng định vai trò, vị trí và tầm quan trọng của quy hoạch, kế hoạch sủ dụng đất đối với quá trình phát triển kinh tế - xã hội.

\section{Tài liệu tham khảo}

1. Bộ Tài nguyên và Môi trường, Thông tu số 19/2009/TT-BTNMT quy định chi tiết việc lập, điều chinh và thẩm định quy hoạch, kế hoạch sủ dụng đất.

2. Bộ Tài nguyên và Môi trường, Thông tu số 29/2014/TT-BTNMT ngày 02 tháng 6 năm 2014 quy định chi tiết việc lập, điều chỉnh quy hoạch, kế hoạch sủ dụng đất.

3. Chính phủ nước Cộng hoà xã hội chủ nghĩa Việt Nam, Nghị định số 68/2001/NĐ-CP ngày 01 tháng 10 năm 2001 về quy hoạch, kế hoạch sử dụng đất đai.

4. Chính phủ nước Cộng hoà xã hội chủ nghĩa Việt Nam (2004), Nghị định số 181/2004/NĐ-CP về thi hành Luật Đất đai.

5. Chính phủ nước Cộng hoà xã hội chủ nghĩa Việt Nam (2009), Nghị định số 69/2009/ND-CP quy định bổ sung về quy hoạch sư dụng đất, giá đất, thu hồi đất, bồi thường, hỗ trợ và tái định cu.

6. Chính phủ nước Cộng hoà xã hội chủ nghĩa Việt Nam, Nghị định số 43/2014/NĐ-CP ngày 15 tháng 5 năm 2014 quy định chi tiết một số điều của Luật Đất đai.

7. Hội đồng Bộ trưởng (nay là Chính phủ), Nghị định số 30/HĐBT ngày 23 tháng 3 năm 1989 về việc thi hành Luật Đất đai.

8. Quốc hội nước Cộng hòa xã hội chủ nghĩa Việt Nam (1987), Luật đất đai 1987. NXB chính trị Quốc gia, Hà Nội.

9. Quốc hội nước Cộng hòa xã hội chủ nghĩa Việt Nam (1993), Luật đất đai 1993. NXB chính trị Quốc gia, Hà Nội.

10. Quốc hội nước Cộng hòa xã hội chủ nghĩa Việt Nam (2003), Luật đất đai 2003. NXB chính trị Quốc gia, Hà Nội.

11. Quốc hội nước Cộng hòa xã hội chủ nghĩa Việt Nam (2013), Luật đất đai 2013. NXB chính 


\title{
BÀI BÁO KHOA HỌC
}

trị Quốc gia, Hà Nội.

12. Quốc hội nước Cộng hòa xã hội chủ nghĩa Việt Nam (2017), Luật Quy hoạch.

13. Quốc hội nước Cộng hòa xã hội chủ nghĩa Việt Nam (2018), Luật số 35/2018/QH14 sưa đổi, bổ sung một số điều của 37 luật có liên quan đến quy hoạch.

14. Tổng cục Địa chính (2001), Thông tu số 1842/2001/TT-TCĐC ngày 01 tháng 11 năm 2001 hướng dẫn thi hành Nghị định số 68/2001/NĐ-CP ngày 01 tháng 10 năm 2001 của Chính Phủ.

15. Tổng cục Địa chính (1995), Quyết định số 657/QĐ-ĐC ngày 28 tháng 10 năm 1995.

16. Tổng cục Địa chính (1998), Công văn số 1814/CV-TCĐC ngày 12 tháng 10 năm 1998.

17. Tổng cục Địa chính (1998), Quyết định số 424a/2001/QĐ-TCĐC ngày 12 tháng 10 năm 1998.

18. Tổng cục Địa chính (2001), Quyết định số 424b/2001/QĐ-TCĐC ngày 01 tháng 11 năm 2001.

19. Tổng cục Quản lý ruộng đất (1991), Thông tư số 106/TT-QLĐĐ ngày 15 tháng 4 năm 1991 huoóng dẫn lập quy hoạch phân bổ đất đai.

\section{THE REAL SITUATION AND PROPOSAL TO INNOVATE AND COM- PLETE THE PROCESS OF MAKING A LAND USE PLAN AND PLAN- NING AT THE PROVINCIAL LEVEL}

\author{
Nguyen Dac Nhan ${ }^{1}$, Pham Thi Hong ${ }^{1}$, Nguyen Manh Thuong ${ }^{1}$ \\ ${ }^{1}$ Department of Land Planning
}

\begin{abstract}
Land use plan and planning play a role in allocating land funds to branches and sectors in order to perform the tasks, objectives, strategies, plans of socio-economic development, national defense and security. Applying traditional scientific research methods such as method of collecting information and document, inheritance method and expert method, the research team studied "The real situation and proposal to innovate and complete the process of making a land use plan and planning at the provincial level" in order to improve the quality and feasibility of the land use plan and planning. Within the scope of this research paper, the research team presented (i) The process of making a plan for land allocation and zoning by functional area and land type to each administrative unit at district level (including 6 items) and (ii) The land use plan-making process at provincial level (including 5 items). The research results are the basis for relevant agencies and localities to refer to apply for making the land use plan and planning for the period of 2021 - 2030.
\end{abstract}

Keywords: Land use planning, process. 